\title{
WILLIAMSONIA LINTNERI (HAGEN); ITS HISTORY AND DISTRIBUTION
}

\author{
By R. Heber Howe, Jr.
}

Belmont, Mass.

A male of this unique species was supposedly figured, without name or description, in 1854 (Emmons, DeKay's Agric. N. Y. 5: Pl. 15.f.1) though the plate is inaccurate as to wing venation (triangle with cross vein) pattern of abdominal markings, and the superior abdominal appendages are shown as distinctly furcate. I feel confident that it was not intended for a figure of this insect. The species was first thought definitely referred to, but not described, by Hagen in 1867 (Stett. ent. Zeit. 28:91) under the title of Diplax vacua,-evidently based on two females collected in 1860, one at Lake Winnipeg and one from the Saskatchewan river (in litt. Hagen) by Robert Kellicott. Later in 1878 (Bull. Acad. Belg. (2) 45:187) Hagen described what he thought to be the same species from material collected at Center, (now Karner) N. Y., naming the insect Cordulia lintneri. The type, a male (No. 2840) was taken on May 27 (1874?), and a female (No. 2839) paratype on May 21 (1874?) by Dr. J. A. Lintner. In a later paper by Hagen (Psyche 5: 371-373. 1890) he again fully described the species, and figured (Pl. 1. fs. 10-17) both sexes, recording at the same time the two females taken by Kellicott which he had formerly named Diplax vacua, but here calls Libellula vacua and which he considered identical. $\mathrm{He}$ made however a significant remark that "It is very interesting that this apparently arctic species is found in eastern New York." In this article Hagen refers to four males and four females as taken by Dr. Lintner, but Dr. E. P. Felt writes me under date of October 17, 1922 that "Knowing what I do of Doctor Lintner, I doubt very much if he ever had four males and four females of this species, though I am unable to explain the significance of the numeral 4 preceding the sign for the male. I am inclined to think it must be a subnumber, though apparently Hagen published his record and 
allowed it to suggest at least four individual males and four individual females. This data as we may infer from Hagen's letter was in manuscript for some time and he doubtless transcribed the labels just as they were and later forgot to call attention to the erroneous construction likely to be placed upon the numeral just before the sex sign or the possibility of any such thing may have escaped his attention." As the label reads $\mathrm{V} 27$ $4 \sigma^{7}$ is it not likely that it meant May 27, 1874, a date that would fit in well with the other facts? In 1895 (Journ. N. Y. Ent. Soc. 3:46) Dr. P. P. Calvert placed the species in the genus Somatochlora, and in 1907 (Cat. Coll. Selys 17:36) Martin referred it to Dorocordulia, and figures (f42) the male abdominal appendages from a photograph sent him of the type by Dr. E. P. Felt. In 1913 (Bull. Brooklyn Ent. Soc. 8:93-96) Mr. Wm. T. Davis proposed for the species a new genus Williamsonia, and figured the wings of a female found in the collection of the American Museum of Natural History, New York taken by John A. Grossback on May 4? at Paterson, N. J.

The two females from Manitoba are not Williamsonia lintneri (Hagen), but represent a different species, Williamsonia fletcheri Will. (Can. Ent. 55:96. 1923). The two specimens collected by Mr. C. H. Young at Mer Bleue, near Ottawa, Canada (48th Ann. Report Ent. Soc. Ont. 25:1915), and specimens collected last May at the same location are also Williamsonia fletcheri though somewhat intermediate and less distinct from $W$. lintneri than the Manitoba specimens which would have supplied better and more characteristic type material. In my opinion it would have been more appropriate to revive the nomen nudum vacua already applied to the species rather than propose a new name. The discovery of the two species explains the supposed two curious distributional "lakes" that have heretofore been attributed to Williamsonia lintneri, the distribution of which is now made clear.

2839. o'. Center, N. Y. May 27, '?4, "a sandy pine woods region" (J. A. Lintner). Coll. State Mus., Albany, N. Y., Bull. Acad. Belg. (2) vol. 45, p. 187 (1878). 
2840. ․ Center, N. Y. May 21, '?4, (J. A. Lintner) Coll. Mus. Comp. Zool., ibid.

๑. Paterson, N. J. May 4, ??, "recorded 1908" (J. A. Crossbeck) Coll. Amer. Mus. Nat. Hist., Bull. Brooklyn Ent. Soc. vol. 8, p. 93, 1913.

$0^{7}$ 우 ㅇ․ Concord, Mass. (E. L. Peirson) Coll. $\sigma^{7}$ Howe, Ent. News, vol. 26, p. 238, 1915, Coll. o Acad. Nat. Sci., Proc. Thoreau Mus. Nat. Hist. vol. 1, p. 41, 1915, 우, destroyed.

$\sigma^{7}$. Framingham, Mass. May 6, 1911 (C. A. Frost) Coll. Boston Soc. Nat. Hist., Mem. Thoreau Mus. Nat. Hist. vol. 8, 1921.

․ Dedham, Mass. May 20,1912, "in low swampy woodland near Wigwam ice pond" (C. W. Johnson). Coll. Boston Soc. Nat. Hist., Ent. News, vol. 26, p. 238, 1915 and Proc. Thoreau Mus. Nat. Hist., vol. 1, p. 41, 1915.

$\sigma^{7}$. Sherborn, Mass. April 30, 1913, "taken in an opening in a scrubby woodland adjoining a wet meadow", (E. J. Smith), Coll. Smith, Psyche, vol. 24, p. 48, 1917.

우 ㅇ. Blue Hills, Milton, Mass. May 13, 1916, "both localities were hilly, rocky and covered with at hick growth of oak, birch and little maple. There was also quite a bit of under-brush. Both streams drained a marsh. That is, they were both outlets for swamps, but in both cases the swamps were small. The streams, themselves, were more or less swift; their water was of that peculiar type, containing a large percentage of organic matter in solution," (W. J. Clench) Coll. Mus. Comp. Zool., Boston Soc. Nat. Hist., Mem. Thoreau Mus. Nat. Hist. vol. II, pt. 4, p. 53, 1919.

ơ. Hopkinton, Mass. May 21, $1916 . \quad$ (C. A. Frost) Coll. Howe, ibid. sup. 8, 1921.

$\sigma^{7}$. Concord, Mass. May 20, 1918 (R. W. Howe, Jr.) Coll. Howe.

$\mathrm{O}^{7}$. Concord, Mass. June 1, 1919. (R. H. Howe, Jr.) Coll. Thoreau Mus. Nat. Hist., Concord, Mass.

9. Middleton, Mass. May 29, 1920. (F. H. Walker) Coll. Peabody Museum, Salem, Mass., Mem. Thoreau Mus. Nat. Hist., vol. II. sup. 8, 1921. 
o. Stony Brook, West Roxbury, Mass. May 6, 1922. (W. J. Clench) Coll. Williamson; Hammonds Pond, Brookline, Mass., May 7, 1922 (R. H. Howe, Jr.) Coll. Howe.

․ Rumford, R. I. May 11, 1922, "near Ten Mile River and Central Pond in "the shadow of Pine and Hemlock woods.... in low growth of scrub mostly oak..... swampy with sphagnum and skunk cabbage growth, also checkerberry and other boreal life." (E. D. Keith) Coll. Howe.

$\sigma^{7}$ ㅇ ㅇ. Stony Brook, West Roxbury, Mass. May 13, 1922, "were flying in the vicinity of a small pond, one of them on a hillside some distance from the water. This pond is a permanent one, surrounded by low land that is covered with water in the spring, and along one side is a bog with sphagnum and Drosera," (Students, Bussey Institution) Coll. Mus. Comp. Zool. Cambridge, Mass. ․ Bos. Soc. Nat. Hist., $q$. Howe.

$0^{7}$. High Rock, Summer Hill, Stoneham, Mass. April, 1, 1923, "in roadway and on rocks," (C. V. Blackburn), Coll. Howe.

ㅇ. Bear Hill, Stoneham, Mass. April 20, 1923, (C. V. Blackburn) Coll. Howe.

․ Bear Hill, Stoneham, Mass. May 5, 1923, (C. V. Blackburn) Coll. P. Garman, Conn. Agric. Expt. Station, New Haven, Conn.

The dates, as will be seen, range from April 1, to June 4, and undoubtedly the reason $W$. lintneri has been overlooked is because of its flight season when collectors are not alive to the presence of Odonata in the field. My own observations of the species bears out the above field notes of other collectors. I always find it a woodland species inhabiting the heighborhood of cold bogs and brook runs, and it alights generally on stones. The orange ring on each abdominal segment makes the insect particularly easy of identification in the field. Its larva is unknown. 

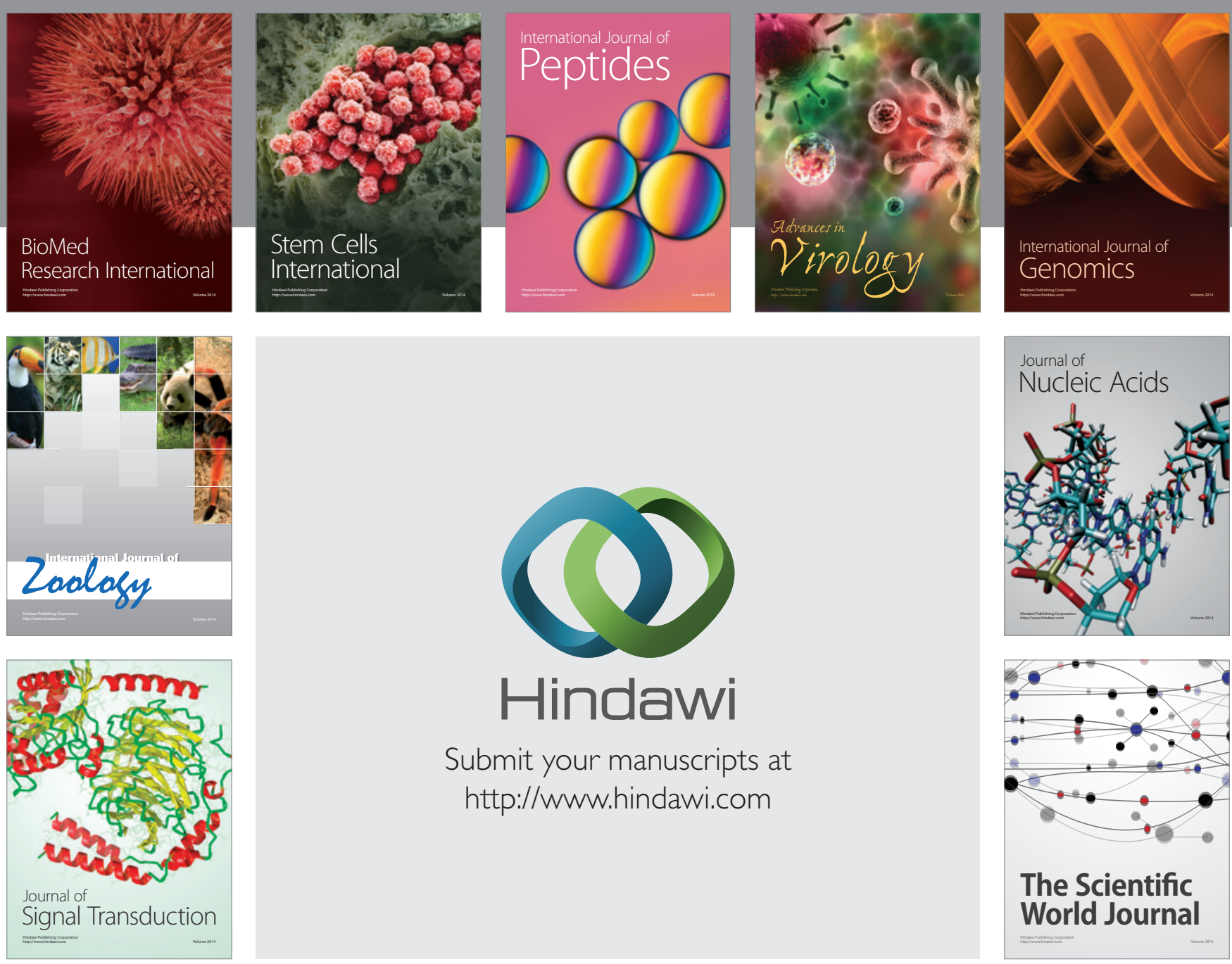

Submit your manuscripts at

http://www.hindawi.com
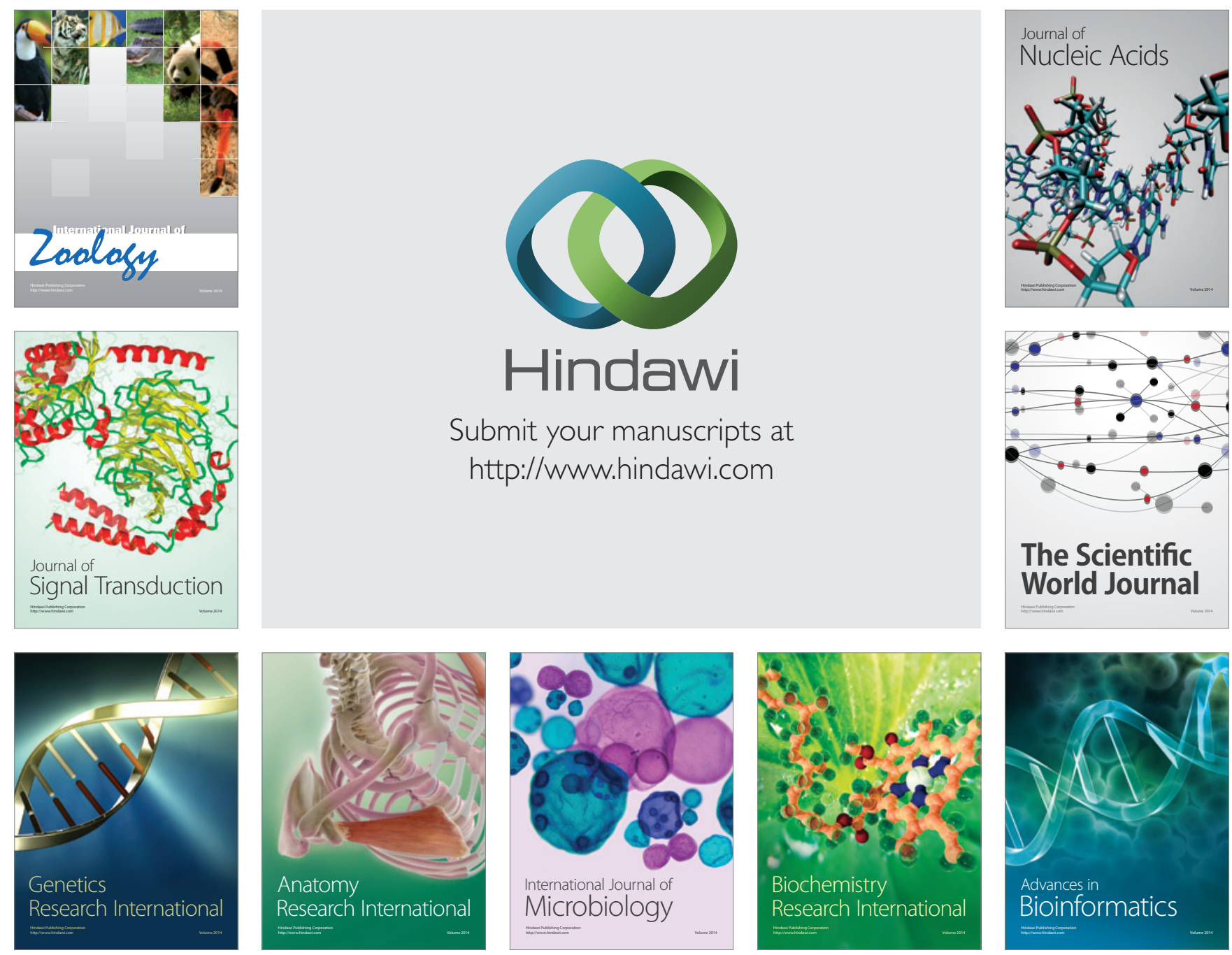

The Scientific World Journal
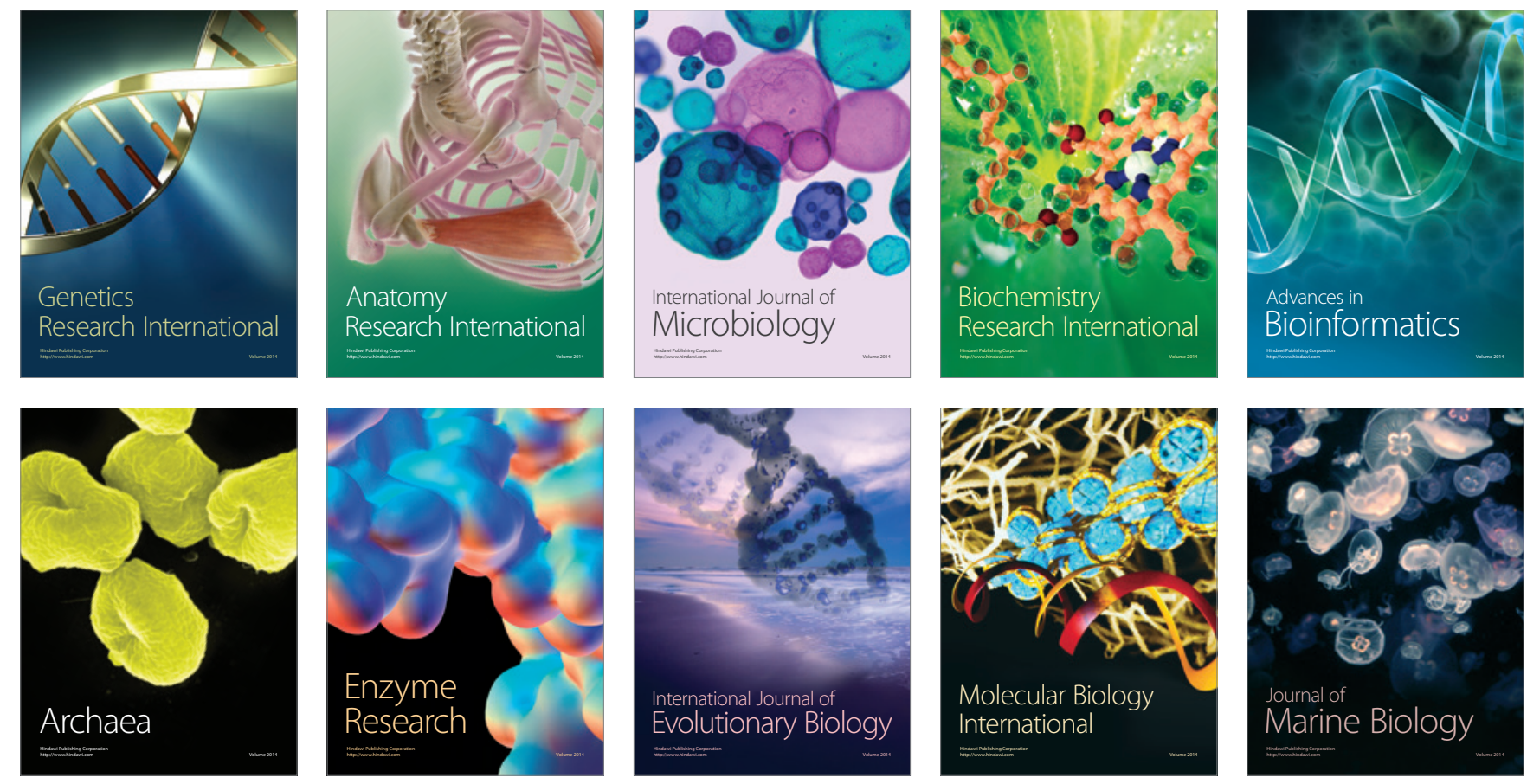